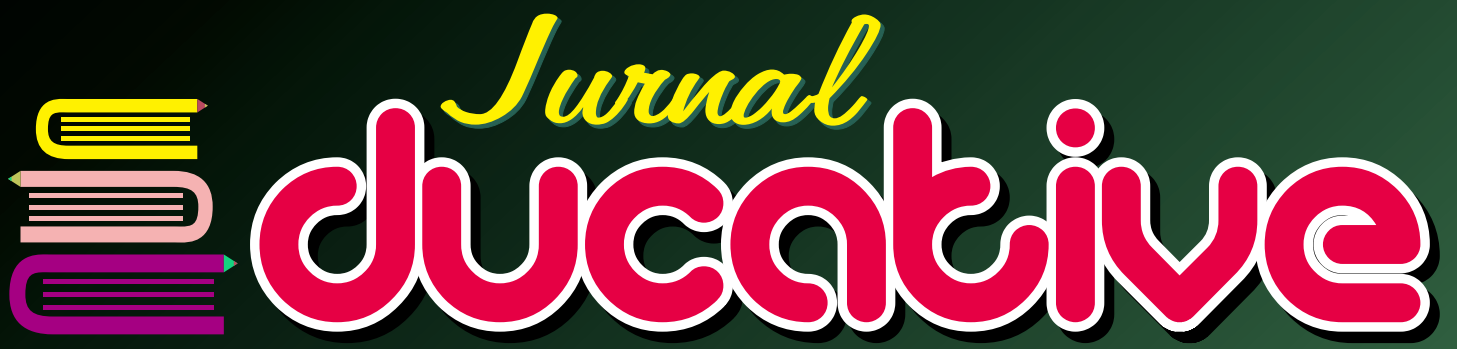 Journal of Educational Studies
}

Pengembangan Bahan Ajar Menulis Ringkasan dan Ikhtisar pada Mata Kuliah Pengembangan Keterampilan Menulis FKIP Universitas Baturaja Muhamad Doni Sanjaya, Muhamad Rama Sanjaya Upaya Meningkatkan Kemampuan Guru Menerapkan Penggunaan Bahan Ajar di SMA Negeri 3 Ogan Komering Ulu Aryanti Agustina

The Islamic Education Strategies Inlocal Culture Perspective of West Sumatera Society

Zulfani Sesmiarni, Junaidi, Darul Ilmi, Wedra Aprison

Problems In Learning Reading

(Case Study: Islamic Banking Students of IAIN Bukittinggi) Widya Syafitri

Teori Laactract dalam Persahabatan Generasi Millenial Qolbi Khoiri

e-Modul Computer Based Learning sebagai e-Resource Digital Literacy bagi Mahasiswa

Novrianti, Nofri Hendri, Ulfia Rahmi

Pengembangan Media Pembelajaran Mobile Learning berbasis Android Pada Mata Kuliah Kecerdasan Buatan Agus Nur Khomarudin, Liza Efriyanti

Meningkatkan Hasil Belajar Siswa Menggunakan Model Make a Match pada Mata Pelajaran IPS Kelas IV di SDN 11 OKU Yelmi Yunarti 


\title{
TEORI LAACTRACT DALAM PERSAHABATAN GENERASI MILLENIAL
}

\author{
Qolbi Khoiri \\ Program Studi Pendidikan Agama Islam - Pascasarjana IAIN Bengkulu \\ E-mail:qolbikhoiri@gmail.com
}

Diterima : 10 Februari $2018 \quad$ Direvisi : 02 April $2018 \quad$ Diterbitkan : 30 Juni 2018

\begin{abstract}
The phenomenon of juvenile delinquency and its relationship with deviant behavior has made enthusiasts and practitioners of education continue to seek alternative solutions to this problem. This is important because the symptoms of its spread are very worrying especially in the era of modernization which is marked by the rapid development of information technology and infiltration of western cultures into private areas, until the millennial generation forms certain groups or gangs that are in accordance with children's comfort, forming this group does not always have a positive impact on one's development, but most of the existence of certain groups has a negative impact on someone. This paper explores the issue in order to find alternative solutions to the problem. The paradigm of revelation used in this paper is QS. QS.49: 13. This study offers the idea of Laactract theory which means that humans as social beings cannot immediately escape the social facts where they are and with whom they are socially confronted, what is needed is to regulate emotions and thoughts in order to always be positive about everything. The regulation of emotions and attitudes can be done with a constructive educational process through heterogeneous communication, in this case bumans strive to realize, achieve and realize what they want (dreamed) by thinking positively, they will definitely be achieved (get)"
\end{abstract}

Keywords: Content, Formatting, Article.

\section{Abstrak}

Fenomena kenakalan remaja dan hubungannya dengan perilaku menyimpang menjadikan peminat dan praktisi pendidikan terus berupaya mencari alternative solusi dari persoalan ini. Hal ini penting dilakukan mengingat gejala penyebarannya sangat mengkhawatirkan terlebih diera modernisasi yang ditandai dengan pesatnya perkembangan teknologi informasi serta infiltirasi budaya barat yang masuk hingga ke wilayah private, hingga akhirnya generasi millennial membentuk kelompok-kelompok atau geng tertentu yang sesuai dengan kenyamanan anak, pembentukan kelompok ini tidak selamanya menimbulkan dampak positif bagi perkembangan seseorang, tetapi sebagian besar adanya kelompok-kelompok tertentu itu mengakibatkan dampak negatif bagi seseorang. Tulisan ini mengeksplorasi persoalan tersebut guna menemukan alternative solusi atas masalah tersebut. Paradigma wahyu yang dipakai dalam tulisan ini adalah QS. QS.49:13. Kajian ini menawarkan gagasan teori Laactract yang bermakna bahwa manusia sebagai makhluk sosial tidak bisa serta merta melepaskan diri dari fakta sosial dimana ia berada dan dengan siapa dia berhadapan secara sosial, yang diperlukan adalah mengatur emosi dan fikiran agar tetap selalu positif terhadap segala hal. Pengaturan emosi dan sikap dapat dilakukan dengan proses pendidikan yang konstruktif melalui komunikasi yang bersifat heterogen, dalam hal ini manusia berupaya merealisasikan, mencapai dan mewujudkan apa-apa yang diinginkan (impikan) dengan berpikir secara positif, pasti akan tercapai (dapatkan)"

Kata Kunci: Laactract, Generasi Millenial

\section{Latar Belakang}

Manusia itu makhluk multidimensional. artinya, manusia itu makhluk rohani dan jasmani, rasional dan moral, serta individual sekaligus sosial. Pada dasarnya manusia adalah makhluk sosial, makhluk yang selalu 
membutuhkan orang lain, dan tidak ada manusia yang berdiri sendiri tanpa peran orang lain. Seperti pada saat seseorang lahir pasti seseorang itu membutuhkan peran orang lain dalam hal ini bisa dokter atau bidan agar sang anak dan ibu bisa selamat. Oleh karena itu, manusia diharuskan dirinya untuk bisa atau pandai berinteraksi dengan yang lain. Dan mau tidak mau manusia harus berinteraksi karena manusia adalah makhluk sosial. ${ }^{1}$

Berinteraksi adalah suatu hal yang sangat penting dan mutlak diperlukan. Berinteraksi bisa dengan siapa saja, baik orang tua, keluarga, teman sebaya, tetangga, dll. Namun pada kenyataannya seseorang biasanya lebih dekat pada temannya yang sebaya dibanding dengan yang lain. Ada beberapa hal seseorang bisa menganggap seseorang menjadi teman. Awalnya secara kebetulan “by accident” karena seseorang tersebut dekat rumahnya, mempunyai hobi yang sama, atau karena seseorang tersebut sekelas. Dan seiring berjalannya waktu seseorang menganggap orang lain sebagai teman adalah karena memilih "by choosing". Memilih disini bisa karena seseorang tersebut satu profesi, satu organisasi, satu pendapat, dan lain sebagainya.

Namun pada hubungan pertemanan sebaya pasti ada suatu problem yang dialami, seperti adanya kecemburuan ketika seseorang yang dianggap sahabat lebih memilih orang lain untuk dijadikan sahabatnya, kemudian terjalinnya hubungan persahabatan diantara seseorang juga menyebabkan kecenderungan diantara anak-anak untuk membentuk kelompok-kelompok atau geng tertentu yang sesuai dengan kenyamanan anak, pembentukan kelompok ini tidak selamanya menimbulkan dampak positif bagi perkembangan seseorang, tetapi sebagian

1 Abdullah Idi, Sosiologi Pendidikan, (Jakarta: PT. Rajagrafindo Persada, 2011), h. 83 besar adanya kelompok-kelompok tertentu itu mengakibatkan dampak negatif bagi seseorang.

Salah satu dampak negatif tersebut tampak pada kalangan remaja khususnya para pelajar, berdasarkan survei 3 dari 10 pelajar di Indonesia pernah merokok sebelum usia 10 tahun, 34,58 persen pelajar tingkat SLTA perokok aktif dan survei Badan Narkotika Nasional (BNN) menunjukkan prevalensi penyalahgunaan narkoba di lingkungan pelajar mencapai 4,7 persen dari jumlah pelajar dan mahasiswa atau sekitar 921.695 orang. ${ }^{2}$

Selain itu, berdasarkan survei Komnas Anak di 12 provinsi dengan responden 4500 remaja tahun 2010 didapat hasil yang sangat mengejutkan. Berdasarkan survei diketahui bahwa 97\% remaja SMP dan SMA pernah melihat film porno, 93,7 \% pernah berciuman hingga petting (bercumbu), $62,7 \%$ remaja SMP sudah tidak perawan, dan 21,2 \% remaja SMA pernah aborsi. ${ }^{3}$

Fitnah syahwat ini bisa dilihat pada kegandrungan mereka pada budaya barat yang mengarah pada, seks and drugs. Opini gaul bebas di kalangan remaja kian gencar dan tanpa hambatan melalui tayangan pornografi dan pornoaksi di layar kaca atau layar lebar. Akibatnya, gaul bebas yang mengarah pada seks bebas kian populer di lingkungan generasi muda. Di Kab. Bandung diperoleh data sedikitnya 38.288 remajanya diduga pernah berhubungan intim di luar nikah atau melakukan seks bebas. Jumlah ini berdasarkan hasil polling "Sahabat Anak Remaja (Sahara) Indonesia Foundation" yang terungkap pada seminar dan lokakarya "Kependudukan dan Kualitas Remaja” di Banjaran. ${ }^{4}$

\footnotetext{
2 Syamsuddin. "Problematika Remaja". Tersedia pada: http://www.indonesia-optimis.com Diakses tanggal 8 Desember 2015.

${ }^{3}$ Syamsuddin. "Problematika...

${ }^{4}$ Harian Pikiran Rakyat, 29 Juli 2014
} 
Ada sejumlah alasan kenapa remaja Bandung melakukan kegiatan seksual pranikah. Hasilnya, upaya menyalurkan dorongan seks (57,89\%), sebagai tanda ungkapan cinta $(38,42 \%)$, terpaksa atau dipaksa pacar $(27,37 \%)$, dan biar dianggap modern $(20,53 \%)$.

Mengenai faktor-faktor yang mempengaruhi terjadinya hubungan seksual pranikah, diperoleh data survei MCR (Mitra Citra Remaja)-PKBI Jabar: sulit mengendalikan dorongan seksual (63,68\%), kurang taat menjalankan agama (55,79\%), rangsangan seksual $(52,63 \%)$, sering nonton blue film (49,47\%), dan tak ada bimbingan orangtua $(9,47 \%)$. Tiga faktor terakhir yang turut menyumbang hubungan seksual pranikah adalah pengaruh tren $(24,74 \%)$, tekanan dari lingkungan (18,42\%), dan masalah ekonomi $(12,11){ }^{6}$

Parahnya, fenomena ini tidak saja terjadi di satu tempat, melainkan hampir merata di seluruh Nusantara. Sekitar 18-20 persen remaja di Indonesia pernah melakukan hubungan seks bebas. ?'Itu hasil penelitian yang pernah kami lakukan terhadap pelajar dan mahasiswa," ujar dr Boyke Dian Nugraha SpOG MARS, saat berbicara dalam acara ?'Let's Talk About Drugs \& Free Sex", Minggu (1/6) di Gedung Dharma Wanita Jateng.

Menelusuri sebab terjadinya berbagai penyimpangan pergaulan remaja tersebut, maka dapat dilihat bahwa dalam perkembangan sosial remaja, teman sebaya sangatlah berperan penting. Peranan temanteman sebaya terhadap remaja terutama berkaitan dengan sikap, pembicaraan, minat, penampilan dan perilaku. Remaja sering kali menilai bahwa bila dirinya memakai model pakaian yang sama dengan anggota kelompok yang populer, maka kesempatan baginya untuk diterima oleh teman-teman sebayanya menjadi besar. Demikian pula bila anggota kelompok mencoba minum alcohol, obat-obatan terlarang atau rokok, maka remaja cenderung mengikutinya tanpa memperdulikan perasaannya sendiri dan akibatnya. Hal ini berarti menunjukkan bahwa kuatnya pengaruh teman sebaya terhadap perkembangan hubungan sosial remaja.

Islam merupakan agama yang sangat memperhatikan keluhuran budi pekerti dan akhlak mulia. Segala sesuatu yang semestinya diiakukan dan segala sesuatu yang semestinya ditinggalkan diatur dengan sangat rinci dalam ajaran Islam, sehingga semakin banyak orang mengakui (termasuk non-muslim) bahwa Islam merupakan ajaran agama yang sangat lengkap dan sempurna serta tidak ada yang terlewatkan sedikit pun.

Seorang mukmin dalam menjalankan kehidupannya tidak hanya menjalin hubungan dengan Allah semata (babluuminallah), akan tetapi menjalin hubungan juga dengan manusia (babluuminannas). Saling kasih sayang dan saling menghargai haruslah diutamakan, supaya terjalin hubungan yang harmonis. Perbedaan bangsa, suku, bahasa, adat, dan kebiasaan menjadi satu paket ketika Allah menciptakan manusia, sehingga manusia dapat saling mengenal satu sama lainnya. Sekali lagi. tak ada yang dapat membedakan kecuali ketakwaannya.

Berdasarkan beberapa persoalan tersebut, sesungguhnya Islam telah memberikan gambaran pola hubungan yang sehat antar sesama manusia, pola hubungan yang sehat tersebut harus dilandasi dengan etika dan estetika yang sesuai dengan perintah Allah Swt

\footnotetext{
5 Tempo Interaktif, 13 Juni 2014

${ }^{6}$ Tempo Interaktif, 13 Juni 2014

${ }^{7}$ Suara Merdeka, 02/06/2003
} 


\section{Paradigma Wahyu}

Berhubungan dengan latar belakang masalah diatas, sesungguhnya Islam telah memberikan ruang bagi manusia untuk saling mengenal antar satu dengan yang lainnya, hal ini tertuang dalam QS.49:13 khususnya pada kalimat.

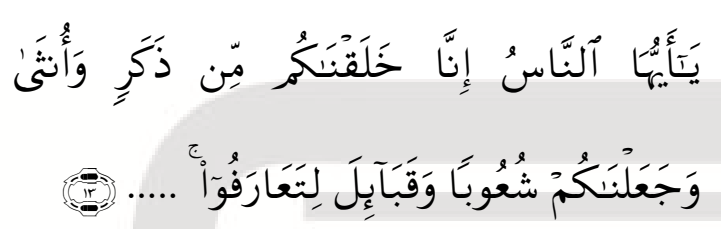

"Hai manusia, Sesunggubnya Kami menciptakan

kamu dari seorang laki-laki dan seorang perempuan dan menjadikan kamu berbangsa bangsa dan bersuku-suku supaya kamu saling kenal-mengenal"

Ayat tersebut penulis jadikan sebagai paradigma wahyu khusunya pada kalimat لتعارفوا (untuk saling mengenal), guna menemukan sebuah teori dalam upaya menjawab pergaulan seperti apa yang yang diajarkan Islam, serta bagaimana memilih teman yang dapat menyelamatkan manusia dunia dan akhirat.

\section{Penjelasan kalimat تتعارفوا}

Menurut Hamka; Surat yang tidak lebih dari 18 ayat ini termasuk surat Madaniah, Ia merupakan surat yang agung dan besar, yang mengandung aneka hakikat akidah dan syariah yang penting, mengandung hakikat wujud dan kemanusiaan. Hakikat ini merupakan cakrawala yang luas dan jangkauan yang jauh bagi akal dan kalbu. Juga menimbulkan pikiran yang dalam dan konsep yang penting bagi jiwa dan nalar. Hakikat itu meliputi berbagai manhaj (cara) penciptaan, penataan, kaidah-kaidah pendidikan dan pembinaan. Padahal jumlah ayatnya kurang dari ratusan. ${ }^{8}$

8 Sayyid Qutbh, Tafsir Fi Zhilalil Qur'an, Terj. As'as Yasin (Jakarta: Gema Insani Press,2004), Cet. I, Jilid X, h. 407
Surat Al-Hujurat berisi pentunjuk tentang apa yang harus dilakukan oleh seorang mukmin terhadap Allah SWT, terhadap Nabi dan orang yang menentang ajaran Allah dan Rasul-Nya, yaitu orang fasik. Pada pembahasan ini dijelaskan apa yang harus dilakukan seorang mukmin terhadap sesamanya dan manusia secara keseluruhan, demi terciptanya sebuah perdamaian. Adapun etika yang diusung untuk menciptakan sebuah perdamaian dan menghindari pertikaian yaitu menjauhi sikap mengolok-olok, mengejek diri sendiri, saling memberi panggilan yang buruk, suudhdhan, tajassus, ghibah, serta tidak boleh bersikap sombong dan saling membanggakan diri karena derajat manusia di hadapan Allah SWT sama.9

Tidaklah ada manusia di dalam alam ini yang tercipta kecuali dari percampuran seorang laki-laki dan perempuan, persetubuhan yang menimbulkan berkumpulnya dua kumpul mani jadi satu, 40 hari lamanya yang dinamakan nuthfah. Kemudian 40 hari lamanya jadi darah, dan 40 hari pula lamanya menjadi daging. Setelah tiga kali empat puluh hari, jadilah dia manusia yang ditiupkan nyawa kepadanya dan lahirlah kedunia.10

Bahwasanya anak yang mulanya setumpuk mani yang berkumpul berpadu satu dalam satu keadaan belum jelas warna tadi, menjadilah kemudian berwarna menurut keadaan iklim buminya,hawa udaranya, letak tanahnya, peredaran musimnya, sehingga tumbuh berbagai warna wajah dan diri manusia dan berbagai pula bahasa yang mereka pakai. Terpisah di atas bumi dalam keluasanya, hidup mencari kesukaanya, sehingga dia pun berpisah berpecah dibawa untung masing-masing kelompok karena dibawa oleh dorongan dan panggilan hidup.

\footnotetext{
${ }^{9}$ Sayyid Qutbh, Tafsir...

${ }^{10}$ Hamka, Tafsir Al-Azhar (Jakarta: Pustaka Panjimas, 1982), Juz XXV , h. 201.
} 
Mencari tanah yang cocok dan sesuai, sehingga lama-kelamaan hasilah apa yang dinamai bangsa-bangsa dan kelompok yang lebih besar dan rata, dan bangsa-bangsa tadi terpecah pula menjadi berbagai suku dalam ukuran lebih kecil terperinci. Dan suku tadi terbagi pula kepada berbagai keluarga dalam ukuran lebih kecil, dan keluara pun terperinci pula kepada berbagai pula kepada berbagai rumah tangga, ibu, bapak dan sebagainya. Di dalamnya disebutkan berbangsa dan bersukusuku sampai kepada perincianya yang lebih kecil, bukanlah agar mereka bertambah lama bertambah jauh, melainkan supaya mereka kenal mengenal. Kenal mengenal darimana asal-usul, dari mana pangkal nenek moyang,dari mana asal keturunan dahulu kala. ${ }^{11}$

Kesimpulanya ialah, bahwasanya manusia pada hakikatnya ialah dari asal keturunan yang satu. Meskipun telah jauh berpisah, namun di asal-usul adalah satu. Tidaklah ada perbedaan di antara yang satu dengan yang lain dan tidaklah ada perlunya membangkit-bangkit perbedaan, melainkan menginsafi adanya persamaan keturunan. ${ }^{12}$ Manusia hidup di dunia bukan buat bermusuhan, melainkan buat berkenalan. ${ }^{13}$

Diakhir ayat disebutkan, bahwa Tuhan Maha Mengetahui, bahwasanya bukan bukan sedikit kebangsaan menimbulkan "ashabiyah jabiliyah" pongan dan bangga karena memikirkan bangsa sendiri, sebagaimana perkataan Hitler ketika naik: "Duitshland ubber alles (Jerman di atas segala-galanya)". Islam telah menentukan langkah yang akan di tempuh dalam hidup, yang semulia-mulia kamu ialah barang siapa yang paling takwa kepada Allah.

\footnotetext{
${ }^{11}$ Hamka, Tafsir...., h. 208

${ }^{12}$ Hamka, Tafsir...., h. 209

${ }^{13}$ Hamka, Tafsir...., h. 210
}

b). Menurut Al-Maraghi : Allah Swt menurunkan ayat ini sebagai cegahan bagi mereka dari membanggakan nasab, mengunggul-unggulkan harta dan menghina kepada orang-orang kafir, dan Allah menerangkan bahwa keutamaan itu terletak pada takwa. ${ }^{14}$

Dan kami menjadikan kalian bersukusuku dan berkabillah-kabilah supaya kamu saling kenal mengenal yakni saling kenal, bukan saling mengingkari. Sedangakan mengejek, mengolok-olok dan menggunjing menyebabkan terjadinya saling mengingkari itu. Kemudian Allah menyebutkan sebab dilarangnya saling membanggakan dengan firmanya:

3). Menurut Quraish Shibab : "Min dzakarin wa Untsa" Dari seorang laki-laki dan perempuan anak adam. Penggalan ayat tersebut adalah pengantar untuk menegaskan bahwa semua manusia derajat kemanusiaanya sama di sisi Allah, tidak ada perbedaan antara satu suku dengan yang lain. Tidak ada perbedaan juga pada nilai kemanusiaan antara laki-laki dan perempuan, karena semua di ciptakan dari seorang laki-laki dan seorang perempuan. ${ }^{15}$

Suku-suku yang bernasab kepada nenek moyang yang terdahulu, maka dari itu manusia sebagai makhluk sosial tidak terlepas dari hubungan interaksi antar sesama manusia oleh karena itu manusia sangat membutuhkan segala yang ada disekelilingnya seperti membutuhkan lingkungan dan setiap manusia pada umumnya sangat membutuhkan lingkungan yang harmunis serta ramah begitu juga saling menghargai satu sama lain seperti hak-hak dan kewajiban manusia, karena lingkungan

14 Ahmad Mustafa Al-Maragi, Tafsir al-Maragi, Terj. Bahrun Abu Bakar dkk (Semarang: CV. Toha Putra, cetakan ke 2, 1992), h. 224-226.

${ }^{15}$ M Quraish Shihab, Tafsir Al-Misbah: Pesan, Kesan Dan Keserasian Al-Qur'an (Jakarta Lentera Hati, 2002), h. 251 
yang seperti inilah yang sangat diinginkan oleh setiap manusia. Dalam menciptakan masyarakat yang tenang, tertib dan penuh dengan keharmonisan, Al-Qur'an merupakan pegangan yang tidak ada keraguan didalamnya. ${ }^{16}$

Ta'arafu berasal dari kata 'Arafa' yang berarti mengenal. Patron kata yang di gunakan ayat ini mengandung makna timbal balik, dengan demikian ia berarti saling mengenal. Semakin kuat pengenalan satu pihak kepada selainya, semakin terbuka peluang untuk saling memberi manfaat. Karena ayat di atas menekankan perlunya saling mengenal. Perkenalan itu dibutuhkan untuk saling menarik pelajaran dan pengalaman pihak lain, guna meningkatkan ketakwaan kepada Allah Swt, yang dampaknya tercermin pada kedamaian dan kesejahteraan hidup duniawi dan kebahagiaan ukhrawi. ${ }^{17}$

Sejak pertama kali muncul, sesungguhnya Islam telah menyeru manusia kepada Ahklak yang baik, ajaran Islam dengan Akhlak yang baik dan Rasul dengan prilaku baiknya telah mampu mengubah bangsa arab jahiliyah dari ummat yang suka melakukan perbuatan yang keji, dholim, mengolok-olok dan berbuat dusta menjadi umat yang saling mencnta dengan sesamanya berkat cahaya iman, sehingga mereka mampu menjadi umat yang memiliki Akhlak yang baik.

Dari berbagai penjelasan tersebut tentunya sudah tidak asing bagi manusia kalau kita melihat fenomena yang terjadi disekeliling kita banyak sekali kejadiankejadian yang tidak mencerminkan sikap dan tingkah laku, seperti: mengolok-olok antara satu sama lain yang mengakibatkan perselisihan dan perbuatan yang tidak meyenangkan, tentu hal ini adalah suatu bukti

${ }^{16} \mathrm{M}$ Quraish Shihab, Tafsir Al-Misbah....,h. 255.

${ }^{17} \mathrm{M}$ Quraish Shihab, Tafsir Al-Misbah....,h. 262. bahwa sikap yang tidak baik sangat tidak diperbolehkan dalam ajaran Islam. Sesuai dengan ajaran-ajaran yang diajarkan didalam pendidikan, Akhlak dari suatu bangsa itulah yang menentukan sikap hidup dan tingkah laku perbuatannya.

Padahal baiknya suatu bangsa akan terlihat dari Akhlaknya. Bagaimanapun juga Akhlak dan perilaku para generasi itu akan sangat menentukan terhadap Akhlak dan perilaku umat-umat sesudahnya, karena regenerasi yang akan datang akan mengikuti atau mencontoh segala yang ada disekelilingnya. Dengan demikian sorotan terhadap Akhlak yang terjadi kepada bangsa kita ini tentunya akan tercermin terhadap para pemimpin-pemimpin yang mempunyai kepentingan untuk para generasi yang akan menggantinya, pendidik juga sebagai pemimpin bagi peserta didiknya, oleh karena itu para pendidik harus mempunyai konsep Akhlak terhadap peserta didiknya agar supaya para peserta didik memiliki budi pekerti yang sesuai dengan ajaran-ajaran agama Islam yang berlandaskan Al-Qur'an dan AlHadits. ${ }^{18}$

Upaya saling mengenal dapat dilakukan dengan proses bersilaturrahim. Untuk menciptakan masyarakat yang harmonis tidak cukup hanya dengan ta'aruf (saling mengenal), akan tetapi harus dibina dan dipupuk dengan subur melalui upaya yang dapat membuat hubungan di antara manusia dapat bertahan lama. Upaya ini dikenal dengan istilah silaturrahim. Silaturrahim artinya menyambungkan tali persaudaraan.

Silaturrahim merupakan sifat terpuji yang harus senantiasa dibiasakan, karena memiliki banyak manfaat. Kenal mengenal tidak memandang warna kulit, ras, bahasa, negara dan lainnya yang seringkali membuat

18 Rahmat Syafi"i, Aqidah, Akblak, Sosial dan Hukum, (Bandung: Pustaka Setia, Cet. II, 2003,) h. 210. 
orang enggan berinterkasi dengan yang lainnya disebabkan karena perbedaan tersebut. Padahal perbedaan-perbedaan tersebut merupakan suatu Sunnatullah dan tidak dapat dijadikan alasan untuk tidak saling mengenal. alasan bahwa diciptakannya manusia adalah untuk saling mengenal dan tolong-menolong, bukan untuk saling membanggakan dan menyombongkan diri, karena kedudukan semua orang adalah sama, hanya ketakwaan yang membedakan antara satu dengan yang lainnya. Bahkan pada hari kiamat nanti seseorang tidak akan ditanya tentang nasab maupun kedudukan mereka, karena yang paling mulia adalah yang paling bertakwa kepada Allah SWT. ${ }^{19}$

\section{Konsep Dasar Manusia}

Telaah ayat-ayat al-Quran yang berbicara tentang manusia, memberi gambaran kontradiktif menyangkut keberadaannya. Disatu sisi manusia dalam alQuran sering mendapat pujian Tuhan. Seperti pernyataan terciptanya manusia dalam bentuk dan keadaan yang sebaik-baiknya, kemudian penegasan tentang dimuliakannya makhluk ini dibanding dengan kebanyakan makhlukmakhluk lain. Sedang di sisi lain sering pula manusia mendapat celaan Tuhan. Seperti bahwa ia amat aniaya dan ingkar nikmat, dan sangat banyak membantah serta bersifat keluh kesah lagi kikir. ${ }^{20}$

Dalam al-Qur'an manusia disebut dengan berbagai nama antara lain: al-Basyr, alInsan, an-Nas, Bani Adam, al-Ins, Abd Allah dan Khalifah Allah. Sehubungan dengan hal ini maka untuk memahami peran manusia, berikut dua hal kata yang berhubungan dengan

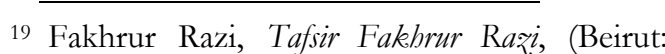
Darul Fikr, Jilid XIV), h. 139

20 Quraish Shihab, Membumikan al-Quran, (Bandung: Mizan, 1994), h. 23 manusia guna dijadikan acuan dalam tulisan ini. $^{21}$

\section{Konsep al-Insan}

Diarahkan pada upaya mendorong manusia untuk berkreasi dan berinovasi. Kata al-insan disebut sebanyak 65 kali dalam alQuran. Hampir semua ayat yang menyebut manusia dengan kata insan, konteksnya selalu menampilkan manusia sebagai makhluk istimewa, secara moral maupun spiritual. Keistimewaan itu tidak dimiliki oleh makhluk lain. Jalaludin Rabmat memberi penjabaran alinsan secara luas pada tiga kategori. Pertama, al-insan dihubungkan dengan keistimewaan manusia sebagai khalifah dan pemikul amanah. Kedua, al-insan dikaitkan dengan predisposisi negatif yang inheren dan laten pada diri manusia. Ketiga, al-insan disebut dalam hubungannya dengan proses penciptaan manusia. Kecuali kategori ketiga, semua konteks al-insan menunjuk pada sifat-sifat psikologis atau spiritual. $^{22}$

\section{Konsep an-Nas}

Konsep al-Nas mengacu pada manusia sebagi makhluk sosial. Manusia dalam arti alnas paling banyak disebut al-Quran yaitu sebanyak 240 kali. Menariknya dalam mengungkapkan manusia sebagai makhluk sosial, al-Quran tidak pernah melakukan generalisasi, melainkan ditunjukkan dengan dua model pengungkapan : (1). Dengan menunjukkan kelompok-kelompok sosial dengan disertai karakteristik masing-masing yang berbeda satu sama lain. Ayat-ayatnya biasanya menggunakan ungkapan wa min al-nas (dan diantara manusia). Jika diperhatikan ayat-

${ }^{21}$ Jalaluddin, Teologi Pendidikan, (Jakarta: Rajawali Grafindo Persada, 2001. h. 12-52

${ }^{22}$ Lebih lanjut dapat dilihat dari berbagai ayat dalam Alquran, diantaranya. QS. Ibrahim : 34, QS. AlIsra : 11, QS. Al-Isra : 100, QS. Al-Ahzab : 72, QS. AnNahl : 4, QS.al-Ma'arij : 19, QS. Al-Insyiqaq : 6, QS. Al-'Adiyat : 6, QS. Al-'Alaq : 6, QS. Maryam : 66 
ayat yang menggunakan ungkapan ini ditemukan petunjuk bahwa ada kelompok manusia (tidak seluruhnya) yang mengaku beriman padahal sesungguhnya tidak beriman (QS. Al-Baqarah: 8), ada sebagian manusia mengambil sesembahan selain Allah (QS. AlBaqarah: 165). Juga didapat informasi bahwa manusia secara sosial cenderung memikirkan kehidupan dunia (QS. Al-Baqarah: 200), berdebat dengan Allah tanpa ilmu, petunjuk dan kitab Allah (QS. Luqman : 20, QS. Al-Hajj : 3,8), yang menyembah Allah dengan iman yang lemah (QS. Al-Haij : 11, QS. Al-'Ankabut : 10). (2). Dengan mengelompokkan manusia berdasarkan mayoritas yang umumnya menggunakan ungkapan aktsaran-nas (sebagian besar manusia). Memperhatikan ungkapan ini ditemukan petunjuk dari al-Quran bahwa sebagian besar (mayoritas) manusia mempunyai kualitas rendah, dari sisi ilmu maupun iman. Hal ini dapat dilihat dari ayatayatnya yang menyatakan bahwa kebanyakan manusia tidak berilmu, tidak bersyukur, tidak beriman, fasiq, melalaikan ayat-ayat Allah, kufur, dan harus menanggung azab. Kesimpulan itu dipertegas dengan ayat-ayat lain yang menunjukkan bahwa sangat sedikit kelompok manusia yang beriman, yang berilmu dan dapat mengambil pelajaran, yang mau bersyukur atas nikmat Allah.

Demikian banyaknya penyebutan kata al-nas dalam al-Quran jika dikaitkan dengan alQuran sebagai petunjuk, menunjukkan bahwa sebagian besar bimbingan Tuhan diperuntukkan bagi manusia sebagai makhluk sosial.

\section{Pendekatan Kajian}

Teori-Teori Sosial Dalam Mengkaji Pertemanan, meliputi : (1). Teori Struktural Fungsional. Pada pertemanan sebaya atau sosialisasi, teori T. Parsons sangat relevan dengan pokok bahasan penyusun. ${ }^{23}$ Menurut Parsons setiap sistem sosial (besar atau kecil ukurannya) harus memenuhi empat kriteria/persyaratan fungsional yang olehnya disingkat menjadi AGIL yang mempunyai arti dari masing-masing huruf yaitu " $\mathrm{A}$ " = "Adaptation", "G" = "Goal Attainment", "I" = "Integration", dan "L" = "Latern Pattern Maintenance". Dalam pertemanan sebaya, keempat fungsi teori T. Parsons masingmasing dilaksanakan oleh subsistem-subsistem berikut beserta penafsirannya; (2). Adaptasi yaitu menyesuaikan diri); Dalam hubungan pertemanan, penyesuaian pribadi dengan sosial merupakan hal yang sangat penting. Oleh karena itu, seseorang harus pandai beradaptasi dengan lingkungannya, dengan teman sebaya sekaligus karakteristiknya. Sebab kelompok teman sebaya merupakan lingkungan sosial pertama tempat seorang belajar untuk hidup bersama orang lain yang bukan anggota keluarganya; (3). Pencapaian tujuan; Hubungan pertemanan pada kelompok sebaya terjalin karena adanya tujuan yang sama diantara anggotanya. Sehingga pemikiran mereka sepaham dan sejalan. Namun, pencapaian tujuan dari hubungan pertemanan itu ada positif dan negatifnya; (4). Integrasi; Setiap keluarga pastinya ada peraturan-peraturan yang harus dipatuhi pada anggota-anggota keluarga tersebut. Hal ini tentunya berkesinambungan dengan pertemanan sebaya, karena keluarga juga berperan dalam pembentukkan karakter si anak dalam proses anak memilih temantemannya. (5). Mempertahankan pola; Maksud dari subsistem ini adalah jangan sampai anakanak ketika menjalin suatu hubungan

${ }^{23}$ Talcott Parsons, The Present Status of StructuralFunctional Theory in Sociology. Dalam Talcott Parsons, Social Systems and The Evolution of Action Theory, New York: The Free Press, 1975)., h. 255-259, selanjutnya juga dapat dilhat dalam penjelasan Jeffrey C Alexander, Revolution, Reaction, and Reform: The Change Theory of Parsons's Middle Period. (tt: Sociological Inquiry, 1981), h. 51: 267-268 
pertemanan keluar dari kaedah-kaedah keluarga, pendidikan, dan agama.

Menurut Robert King Merton seorang tokoh sosiologi modern, tokoh struktural fungsional bahwa seseorang harus berhati-hati dalam bertindak dan memilih teman, karena bisa jadi keberhasilan dalam bertindak justru menciptakan masalah yang berat. Seperti seseorang telah menemukan teman yang sangat cocok dan dia sangat dekat dengan temannya, sehingga dapat mencurahkan segala yang di rasa terhadap temannya (fungsional) akan tetapi jika seseorang sangat dekat dengan temannya maka secara tidak sadar seseorang tersebut lambat laun menjadi jauh dengan keluarganya sendiri yang dimana posisi keluarga adalah sebagai agen sosialisasi yang pertama (disfungsional). Oleh karena itu, seseorang harus pandai bersosialisasi baik dengan keluarganya, teman, dan masyarakat sekitar agar tidak terjadi disfungsional yang sangat besar. ${ }^{24}$

Akhir dari analisis ini adalah visi metafisis yang besar oleh dunia yang telah menimpa eksistensi manusia. Analisis parson merepresentasikan suatu usaha untuk mengkategorisasikan dunia kedalam sistem, subsistem, persyaratan-persyaratan system, generalisasi media dan pertukaran menggunakan media tersebut. Analisis ini pada akhirnya lebih filosofis daripada sosiologis, yakni pada lingkup visi meta teori. Pembahasan mengenai fungsionalisme Merton diawali pemahaman bahwa pada awalnya Merton mengkritik beberapa aspek ekstrem dan keteguhan dari structural fungsionalisme, yang mengantarkan Merton sebagai pendorong fungsionalisme kearah marxisme. Hal ini berbeda dari sang guru, Talcott Parson mengemukakan bahwa teorisi structural

${ }^{24}$ Robert King Merton, Social Theory and Social Structure, revised and enlarged. (London: The Free Press of Glencoe. (1957))., h 234 fungsional sangatlah penting.Parson mendukung terciptanya teori yang besar dan mencakup seluruhnya sedangkan parson lebih terbatas dan menengah.

\section{Teori Konflik}

Setiap individu menginginkan perubahan, dan tentunya perubahan tersebut ke arah yang lebih positif. Awalnya seorang anak begitu dekat dengan keluarganya karena memang keluarga adalah agen sosialisasi pertama dalam kehidupannya. Akan tetapi, setelah dia menginjak dunia luar, seorang anak tersebut merasa asing karena memang belum mengenal dunia luar dan seorang anak hanya mengenal keluarganya. Lambat laun, karena seorang anak sering berinteraksi, bersosialisasi dengan dunia luar maka seorang anak tersebut akan mendapat kenyamanan, dan biasanya kenyaman tersebut didapat dari seorang teman, baik anak tetangga ataupun teman sekelasnya di sekolah. Karena anak tersebut sudah merasa nyaman dengan kehadiran teman-temannya maka secara perlahan anak tersebut menggeser fungsi keluarga dengan fungsi teman. Dan teman adalah agen sosialisasi yang kedua setelah keluarga.

"Menurut Pierre Bourdieu babwa setiap individu mempunyai pertimbangan tersendiri mengenai berbagai hal. Seperti halnya dalam berteman, seseorang lebib nyaman dengan si $A$ daripada si $B$, dan seseorang lebih nyaman dengan si $C$ daripada si $A$. Perbedaan ini sering terjadi dalam kebidupan sehari-hari. Seseorang mencari teman yang nyaman dengan dirinya. Dan hal ini dapat terjadi karena setiap individu mempunyai pandangan, mempunyai pertimbangan masing-masing terhadap temannya. ${ }^{25, "}$

25Pierre Bourdieu, Distinction : a social critique of the judgement of taste. Cetakan ke-8, translated by Richard Nice. (Cambridge: Harvard University Press,1996..)., h. 70 


\section{Teori Pertukaran (Exchange)}

Manusia selalu berusaha mencari keuntungan dalam interaksi atau berhubungan dengan sesama. Dalam hubungan dengan teman tidak ada seorang pun yang dirugikan karena manusia selalu memperhitungkan untung dan rugi dalam segala aspek kehidupan. Jika seseorang ingin mendapatkan keuntungan maka akan ada sesuatu yang dipertukarkan, baik itu berupa barang, perasaan ataupun jasa. Sebagai contoh pertukaran dengan teman yaitu, jika seseorang merasa nyaman dengan temannya dan tiba-tiba seseorang tersebut mendapatkan nilai yang bagus dalam ujian karena seseorang tersebut belajar kepada temannya. Dan temannya juga merasa senang telah berhasil membantu seseorang tersebut sehingga mendapatkan nilai yang memuaskan.

Inti dari teori pembelajaran sosial dan pertukaran sosial adalah perilaku sosial seseorang hanya bisa dijelaskan oleh sesuatu yang bisa diamati, bukan oleh proses mentalistik. Semua teori yang dipengaruhi oleh perspektif ini menekankan hubungan langsung antara perilaku yang teramati dengan lingkungan. Para teoritikus Pertukaran Sosial berpendapat bahwa semua orang menilai hubungan mereka dengan melihat pengorbanan dan penghargaan. Semua hubungan membutuhkan waktu dari partisipannya.

Hubungan yang positif adalah hubungan di mana nilainya merupakan angka positif; maksudnya, penghargaan lebih besar daripada pengorbanan. Hubungan di mana nilainya adalah angka negatif (pengorbanan melebihi penghargaan) cenderung negatif untuk para partisipannya. Teori Pertukaran Sosial bahkan melangkah lebih jauh dengan memprediksikan bahwa nilai dari sebuah hubungan memengaruhi hasil akhir atau apakah orang akan meneruskan suatu hubungan atau mengakhirinya. Hubungan yang positif biasanya dapat diharapkan untuk bertahan, sedangkan hubungan yang negatif mungkin akan berakhir. ${ }^{26}$

\section{Teori Labelling}

Lahirnya teori labeling, diinspirasi oleh perspektif interaksionisme simbolik dan telah berkembang sedemikian rupa dengan risetriset dan pengujiannya dalam berbagai bidang seperti, kriminolog, kesehatan mental, kesehatan dan pendidikan. Menurut Sunarto, teori labelling dipelopori oleh Lemert dan Interaksionisme simbolik dari Herbert Mead. Kemudian dikembangkan oleh Howard Becker pada tahun 1963. Menurut teori Labelling bahwa setiap tatanan masyarakat mempunyai label atau julukan masing-masing seperti kelompok "rajin", "tukang usil", dsb. Hal ini juga terjadi pada hubungan pertemanan. Dalam hubungan pertemanan kita dapat menjumpai adanya kelompokkelompok seperti "gang". Kelompokkelompok tersebut bersosialisasi dengan kelompoknya sendiri, kelompok yang lain, dan masyarakat. Kelompok tersebut biasanya mempunyai julukan atau label tersendiri, seperti kelompok "rempong", kelompok "rajin", kelompok "centil". Julukan ini berdasarkan atas pengamatan orang lain terhadap suatu kelompok. ${ }^{27}$

\section{Tahapan Interaksi Sosial Anak melaui Peer Group}

Berbeda dengan proses sosialisasi dalam keluarga yang melibatkan hubungan yang tidak sederajat (berbeda usia, pengalaman dan peranan), sosialisasi dalam kelompok sebaya dilakukan dengan cara mempelajari pola interaksi dengan orang-orang yang sederajat

26 Ahmad Sihabudin, Komunikasi Antar Budaya Sebuah Perpektif Multidimensi, (Jakarta: PT. Bumi Aksara, 2011), h 56

${ }^{27}$ K. Sunarto, Pengantar Sosiologi (edisi revisi), (Jakarta: Lembaga Penerbit Fakultas Ekonomi Universitas Indonesia, 2004), h. 80 
dengan dirinya. Karena itulah dalam kelompok sebaya, anak dapat mempelajari peraturan yang mengatur peranan orang-orang yang kedudukannya sederajat dan juga mempelajari nilai-nilai keadilan.

\section{Pada masa anak-anak awal}

Sejumlah penelitian telah merekomendasikan betapa hubungan social dengan teman sebaya memiiki arti yang sangat penting bagi perkembangan pribadi anak. Salah satu fungsi kelompok peer group yang paling penting adalah menyediakan suatu sumber informasi dan perbandingan tentang dunia di luar keluarga. Anak-anak menerima umpan balik tentang kemampuan-kemampuan mereka dari kelompok teman sebaya. Anakanak mengevaluasi apakah yang mereka lakukan lebih baik, sama atau lebih jelek dari yang dilakukan oleh anak-anak lain. Mereka menggunakan orang lain sebagai tolak ukur untuk membandingkan dirinya. Proses pembandingan social ini merupakan dasar bagi pembentukan rasa harga diri dan gambaran diri anak. ${ }^{28}$

\section{Pada masa pertengaban dan akbir anak-anak.}

Seperti halnya dengan masa awal anakanak, berinteraksi dengan teman sebaya merupakan aktivitas yang banyak menyita waktu anak selama masa pertengahan dan akhir-anak. Barker dan Wright (dalam Santrock, 1995) mencatat bahwa anak-anak usia 2 tahun menghabiskan 10\% dari waktu siangnya untuk berinteraksi dengan teman sebaya. Pada usia 4 tahun, waktu yang dihabiskan untuk berinteraksi dengan teman sebaya meningkat menjadi 20\%. Sedangkan anak usia 7 hingga11 meluangkan lebih dari

${ }_{28}$ Desmita. Psikologi Perkembangan. (Bandung : PT. Remaja Rosdakarya. 2005)., h 184
$40 \%$ waktunya untuk berinteraksi dengan teman sebaya. ${ }^{29}$

\section{Pada masa remaja}

Seorang remaja yang telah mantap dengan keberadaan dirinya akan lebih percaya diri memulai hubungan dengan orang lain. Ketika menjalin relasi dengan orang lain ia tidak akan berorientasi pada dirinya sendiri melainkan akan menaruh keberadaan di luar dirinya. Hal ini tampak pada remaja yang memberikan rasa kepedulian kepada temannya yang dikenal, remaja akan lebih aman bila membagikan permasalahan, ide-ide, pkiranpikiran yang dimiliki untuk dibagikan pada orang lain yang dikatakan teman atau sahabat. ${ }^{30}$

Sekali terbangun suatu hubungan akrab, dibandingkan dengan hubungan biasa akan mengakibatkan dua individu atau lebih menghabiskan banyak waktu yang lebih bervariasi menjadi self-disclosing, saling memberikan dukungan emosional dan membedakan antara sahabat dan teman lainnya. Teman biasa adalah seseorang yang menyenangkan untuk bersama, sementara sahabat dihargai karena ia murah hati, sensitive, dan jujur. Seseorang yang dapat diajak bersantai dan menjadi diri kita sendiri.

Kuatnya pengaruh teman sebaya tidak terlepas dari adanya ikatan yang terjalin kuat dalam kelompok teman sebayanya tersebut (peer group), sedemikian kuatnya sehingga mengarah ke fanatisme. Sehingga tiap-tiap anggota kelompok menyadari bahwa mereka adalah satu kesatuan yang terkait dan saling mendukung. Di mana kelompok teman sebaya (peer group) merupakan kelompok yang terdiri dari teman seusianya dan mereka dapat mengasosiasikan dirinya (Chaplin, 2001). Dan

${ }^{29}$ A. Robert Baron. Psikologi Sosial Jilid 2 Edisi Sepuluh. (Jakarta : Erlangga, 2003)., h. 9

${ }^{30}$ Desmita. Psikologi...h. 79 
juga menurut Santrock (2003), pada banyak remaja, bagaimana mereka dipandang oleh teman sebaya merupakan aspek yang terpenting dalam kehidupan mereka. Bahkan remaja akan melakukan apapun, agar dapat dimasukkan sebagai anggota. Untuk mereka, yang tidak kohesi atau mengikuti aturan kelompoknya akan dikucilkan dan berarti stres, frustasi, dan kesedihan.

Dalam Peer group, individu merasakan adanya kesamaan satu dengan yang lainnya seperti bidang usia, kebutuhan dan tujuan yang dapat memperkuat kelompok itu. Di dalam Peer group tidak dipentingkan adanya struktur organisasi, namun diantara anggota kelompok merasakan adanya tanggung jawab atas keberhasilan dan kegagalan kelompoknya. Dalam Peer group, individu merasa menemukan dirinya serta dapat menegmbangkan rasa sosialnya sejalan dengan perkembangan kepribadiannya.

tanpa melibatkan unsure spiritual yang sifatnya transendental.

Berbeda dari beberapa teori yang telah ada, teori Laactract yang penulis kemukakan dalam tulisan ini adalah teori law of attraction yang mengandung arti bahwa manusia sebagai makhluk sosial tidak bisa serta merta melepaskan diri dari fakta sosial dimana ia berada dan dengan siapa dia berhadapan secara sosial, yang diperlukan adalah mengatur emosi dan fikiran agar tetap selalu positif terhadap segala hal.

Secara harfiah pengertian Law Of Attraction dapat diartikan sebagai "Hukum Tarik-Menarik". Pengertian maknawinya kalau boleh diperjelas adalah " Bahwa kita bisa merealisasikan, mencapai dan mewujudkan apa-apa yang kita inginkan (impikan) apabila kita bisa berpikir secara positif dan yakin bahwa keinginan (mimpi) kita tersebut pasti akan kita capai (dapatkan)"

Hukum tarik-menarik adalah sunnatullah,

\section{Temuan Teori}

Beberapa penjelasan yang telah penulis uraikan pada bagian terdahulu dan juga berdasarkan rumusan pendekatan teori interaksi sosial yang telah di disajikan, maka penulis dapat merumuskan teori yang penulis beri nama Teori Laactract.

Teori ini berdasarkan paradigma wahyu QS. 49:13 yang menjelaskan bahwa Allah Swt telah menciptakan manusia dengan berbagai kompleksitasnya, namun satu hal yang menjadi prinsip utamanya dalam pergaulan adalah bahwa yang terbaik diantara jenis kelamin, suku, golongan dan ras adalah ketakwaan.

Beberapa teori mengenai interaksi sosial yang diketengahkan oleh pakar sesungguhnya memuat beberapa hal yang bertentangan dengan prinsip dasar QS. 49:13, dimana mereka hanya melihat aspek sosiologis semata ia tidak memilih orang, siapapun mengalaminya. Ia juga tidak memandang pikiran baik atau buruk, mau atau tidak mau, ia hanya menerima signal dari pikiran anda dan memantulkannya kembali. Ketika seseorang fokus pada sesuatu sebenarnya ia sedang memanggil sesuatu itu untuk hadir dalam hidupnya. Ini merupakan manivestasi rahmat Allah yang berlaku untuk seluruh makhluknya, tidak melihat apapun agamanya, tabi'atnya, ketakwaannya dan maksiatnya.

Allah senantiasa menganjurkan kita supaya berlomba-lomba menebarkan kebaikan (fastabiqul khairot). Allah sangat melarang kita berbuat kekasaran (sayyiaat) dan kerusakan (fasaad). Bahkan, kepada orang yang selalu berbuat jahat, kita pun harus bersikap baik padanya. 
Lebih jelasnya skema teori ini penulis gambarkan berikut ini :

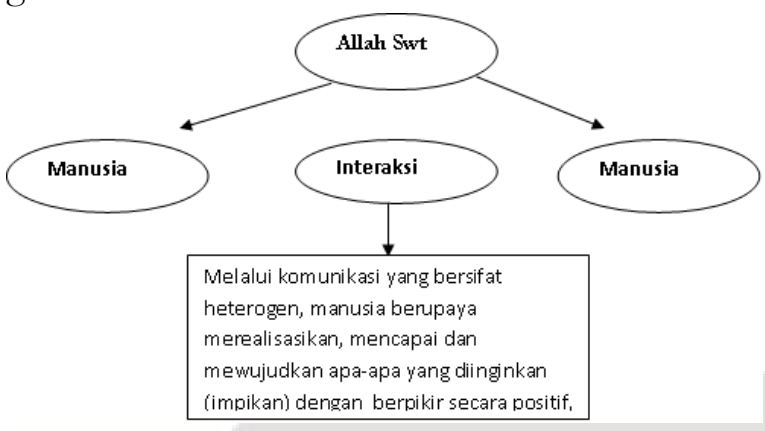

\section{Kesimpulan}

Hubungan pertemanan sebaya pada aspek tertentu ada suatu problem yang dialami, seperti adanya kecemburuan ketika seseorang yang dianggap sahabat lebih memilih orang lain untuk dijadikan sahabatnya, kemudian terjalinnya hubungan persahabatan diantara seseorang juga menyebabkan kecenderungan diantara anak-anak untuk membentuk kelompok-kelompok atau geng tertentu yang sesuai dengan kenyamanan anak, pembentukan kelompok ini tidak selamanya menimbulkan dampak positif bagi perkembangan seseorang, tetapi sebagian besar adanya kelompok-kelompok tertentu itu mengakibatkan dampak negatif bagi seseorang.

Menelusuri sebab terjadinya berbagai penyimpangan pergaulan remaja tersebut, maka dapat dilihat bahwa dalam perkembangan sosial remaja, teman sebaya sangatlah berperan penting. Secara kodrati, Allah swt menciptakan manusia dengan berbagai jenis kelamin, suku dan ras serta golongan sesungguhnya memiliki misi ta'aruf, hal ini jelas tertuang dalam QS. 49:13.

Pada penjelasan ayat termaktub bahwa ta'aruf yang dimaksud adalah perkenalan yang bermuara pada pertemanan positif, dan Islam mengajarkan umatnya untuk saling kenal mengenal (simbiosis mutualistis).

Terdapat berbagai macam teori mengenai interaksi sosial dalam hal pergaulan atau pertemanan, diantaranya teori struktur fungsional yang dikembangkan oleh $\mathrm{T}$. Parsons, teori konflik yang dikembangkan oleh Pierre Bourdieu, teori pertukaran (exchange) dan teori labeling.

Pada tulisan ini kemudian menawarkan teori baru yang penulis namakan teori laatract, berbeda dari beberapa teori yang telah ada, teori Laactract yang penulis kemukakan dalam tulisan ini adalah teori law of attraction yang mengandung arti bahwa manusia sebagai makhluk sosial tidak bisa serta merta melepaskan diri dari fakta sosial dimana ia berada dan dengan siapa dia berhadapan secara sosial, yang diperlukan adalah mengatur emosi dan fikiran agar tetap selalu positif terhadap segala hal

\section{Daftar Pustaka}

\section{Buku Teks}

Alexander, Jeffrey C, Revolution, Reaction, and Reform: The Change Theory of Parsons's Middle Period. tt: Sociological Inquiry, 1981

Al-Ghazali Ihya' Ulum al-din Juz III Surabaya : Hidayah, tt

Baron, Robert A, Psikologi Sosial Jilid 2 Jakarta : Erlangga, 2003, edisi Sepuluh

Bourdieu, Pierre, Distinction : a social critique of the judgement of taste. Cetakan ke-8, translated by Richard Nice. Cambridge: Harvard University Press,1996

Desmita. Psikologi Perkembangan. Bandung : PT. Remaja Rosdakarya. 2005

Hamka, Tafsir Al-Az̧har Jakarta: Pustaka Panjimas, 1982, Juz XXV

Hartup, Willard W. and Nan Stevens, Friendships and Adaptation Across the Life Span, Blackwell Publishers, Inc: Institute 
of Child Development University of Minnesota, 1999

Holmes, J. G. Trust and the appraisal process in close relationships. In W. H. Jones \& D. Perlman (Eds.), Advances in personal Relationships, London: Jessica Kingsley. 1997

Idi, Abdullah, Sosiologi Pendidikan, Jakarta: PT. Rajagrafindo Persada, 2011

Jalaluddin, Teologi Pendidikan, Jakarta: Rajawali Grafindo Persada, 2001

Jamieson DW, Lydon JE, Holmes JG.The meaning of social interactions in the transition from acquaintanceship to friendship, Montreal, Quebec, Canada: Department of Psychology, McGill University

Merton, Robert King, Social Theory and Social Structure, revised and enlarged. (London: The Free Press of Glencoe. 1957

Mustafa Ahmad, Al-Maragi, Tafsir al-Maragi, Terj. Bahrun Abu Bakar dkk Semarang: CV. Toha Putra, cetakan ke 2, 1992

Parsons, Talcott, The Present Status of StructuralFunctional Theory in Sociology. Dalam Talcott Parsons, Social Systems and The Evolution of Action Theory, New York: The Free Press, 1975

Qutbh, Sayyid, Tafsir Fi Zhilalil Qur'an, Terj. As'as Yasin Jakarta: Gema Insani Press,2004, Cet. I, Jilid X

Razi, Fakhrur, Tafsir Fakhrur Razi, Beirut: Darul Fikr, Jilid XIV

Saleh, Qamaruddin, dkk, Asbab Nuzul (Latar Belakang Historis Turunya Ayat-Ayat AlQur'an) Bandung: Diponegoro, Cet X, 1988.

Shihab, M Quraish, Tafsir Al-Misbah: Pesan, Kesan Dan Keserasian Al-Qur'an Jakarta Lentera Hati, 2002), hal. 251
Membumikan al-Quran, Bandung: Mizan, 1994

Sihabudin, Ahmad, Komunikasi Antar Budaya Sebuah Perpektif Multidimensi, Jakarta: PT. Bumi Aksara, 2011

Sunarto, K. Pengantar Sosiologi (edisi revisi), Jakarta: Lembaga Penerbit Fakultas Ekonomi Universitas Indonesia, 2004

Syafiei, Rahmat, Aqidah, Akblak, Sosial dan Hukum, Bandung: Pustaka Setia, Cet. II, 2003

Wahab, Ramli Abdul, Ulum Al-Qur'an, Jakarta: Raja Grafindo Persada, 1996

\section{Jurnal Ilmiah}

Zajonc, Robert B, Attitudinal Effects Of Mere Exposure. Journal of Personality and Social Psychology, Vol 92, Pt.2, Jun 1968

\section{Media Cetak dan Online}

Harian Pikiran Rakyat, 29 Juli 2014

Suara Merdeka, 02/06/2003

Tempo Interaktif, 13 Juni 2014

Syamsuddin. "Problematika Remaja". Tersedia pada: $\quad$ http://www.indonesiaoptimis.com Diakses tanggal 8 Desember 2015. 